UDC: 378.147-057.875::37.091.2:159.9-021.311

DOI: 10.26697/ijes.2019.2.16

\section{Some Methods of the Leader-Patriot Personality Formation Among the Students in the Study of General Psychology}

\author{
Associate Professor Oleksyuk O. Ye. ${ }^{1}$ \\ ${ }^{1}$ Mykolaiv V. O. Sukhomlynskyi National University, \\ Ukraine
}

\begin{abstract}
Background:

The concept of the New Ukrainian School has defined certain prerogatives as part of the comprehensive institution graduate model, and therefore modern specialists in the educational sphere themselves must meet the same requirements. One of these components is patriotism. Having analyzed the scientific researches, the current state of a social life, the course of political events taking place in the country, it can be concluded that it is not enough to educate only the patriotic youth. At present, there is a big problem in our country with the presence of the leader-patriot personalities.
\end{abstract}

\begin{abstract}
Methods:
The outlined problem has set requirements for updating the forms, methods and techniques of training a modern teacher in different educational fields. The search for creative new approaches to the introduction of ideas for the formation of the leader-patriot qualities among the students has led to an appeal to the technology of developing critical thinking and the selection of some characteristic methods, such as a method-press, a cinquain method, a letter-reflection, an essay, etc.
\end{abstract}

\footnotetext{
Results:

The theoretical analysis of the method of cinquain technology for the development of critical thinking and the author's version of the presentation of this method has made it possible to determine the priority attitude of students to the key concepts of the scientific research topic: country, patriot, peace, war, leader, hero, invader, defender. Students, studying the topic "Cognitive Psychic Processes. Thinking", had the task of the independent work to make up the cinquain with the listed words, choosing the rank of priority for writing the poem which was not rhymed. As there were only eight words-objects in ranking, the ranking was in the range of 1 to 8 . The results of the study on the degree of the words-objects ranking are given (in brackets the average rank results are shown): 1 country (3.05); 2 - peace $(3.43) ; 3$ - patriot (4.05); 4 hero $(4,12) ; 5$ - war $(4.63) ; 6$ - leader $(5.15) ; 7$ defender (5.33); 8 - invader (6.33). The ranking shows that students nowadays, first of all, think about their country and wish peace to it; show patriotic feelings and understand the importance and heroic contribution of people to the establishment of sovereignty of the state, especially during military events. The value of leadership is lowered, but it is in the same range with the role of a defender. A negative attitude of students is
}

shown to the invaders, enemies of their country, as evidenced by the last rank.

The analysis of key characteristics, for example, the concept of "country", shows that $26.7 \%$ of respondents have written "Ukraine", $20.0 \%$ of responders have indicated that it is "Motherland" for them, that is, the identification is made on the basis of territoriality.

The second highest rank is the concept of "peace". It has been characterized as "calm" by $23.3 \%$ of students. $16.7 \%$ of students believe that "peace" will bring "joy" and "happiness", and $13.3 \%$ prefer such characterological notions as "desired" and "harmony". The results of the study on the theme of "patriot" show that $20.0 \%$ of the respondents have identified it with the notion of "defender" and $13.3 \%$ of the students have indicated the word "country" in the summary.

The characterization of such a person is described as "courageous" (10\%). $6 \%$ of responders have identified it with the notion of "hero" and $6 \%$ of students have identified it with "devotion".

The next on the value of the essential content is the concept of "hero". Among the respondents, 20.0\% have indicated that it is "man", "soldier", "leader". For $16.7 \%$ of students this is "defender", "protector". The same number of participants in the study - 16.7\% describes the hero as having "courage" and "bravery". And $13.3 \%$ of young people consider the hero to be an unconquerable hero and a supporter. For our research, it was important to find out how the students understand the concept of "leader" and to what extent it is associated with patriotism. $33.3 \%$ of students characterize "leader" as the "main", who goes ahead. $13.3 \%$ of responders have determined that he is "smart" and "brave".

There is no attachment of this concept to patriotism, indicating that students are not sufficiently aware of the importance of such a connection for the further strengthening of the country.

\section{Conclusions:}

The analysis of only one of the used methods of technology of critical thinking, namely the method of cinquain, showed the possibility of conducting the elements of educational impact on students during the educational process in order to form the patriot-leader qualities through their role awareness for the future of the country.

Information about the author:
Oleksyuk Oksana Yevhenivna - Doctor of
Philosophy in Pedagogy, Associate Professor of the
Department of Pedagogy and Inclusive Education,
Mykolaiv V. O. Sukhomlynskyi National University,
Mykolayiv, Ukraine.
Research interests: the formation of the future
specialist's personality in the educational space,
patriotic education of student youth.

\section{Corresponding Author:}

Oleksyuk Oksana Yevhenivna

\section{Corresponding Author's Email:}

oleksjukoksana@ukr.net 